\title{
Biosorption of an industrial dye (A-BG) by a dairy sludge
}

\author{
Mohamed Sassi $^{1, *}$, Benaouda Bestani $^{2}$, Eric Guibal $^{3}$ \\ ${ }^{1}$ Faculty of Nature and Life Sciences, Ibn Khaldoun University - Tiaret, Agro-biotechnology and Nutrition Laboratory in Semi-arid Zone, BP \\ 78 ZAAROURA - 14000 Tiaret, Algeria \\ ${ }^{2}$ Laboratoire de Structure, Elaboration et Application des Matériaux Moléculaires, Université de Mostaganem, Mostaganem, Algeria \\ ${ }^{3}$ Ecole des Mines Alès, Engineering Laboratory of the Industrial Environment, 6 Avenue de Claviere, F-30319 Alès CEDEX, France
}

\section{Email address: \\ mo_sassi@yahoo.fr(Md. Sassi)}

\section{To cite this article:}

Mohamed Sassi, Benaouda Bestani, Eric Guibal. Biosorption of an Industrial Dye (A-BG) by a Dairy Sludge. American Journal of Environmental Protection. Vol. 3, No. 5, 2014, pp. 292-298. doi: 10.11648/j.ajep.20140305.23

\begin{abstract}
Dairy sludge was investigated as potential adsorbent for the removal of hazardous cationic dyes. Biosorption was studied as a function of solution initial $\mathrm{pH}$, biosorbent dose, biosorbent particle diameter and initial dye ion concentration. These parameters were measured in batch experiments. Equilibrium uptake increased with increasing dye concentration with a maximum sorption capacity of a $178.6 \mathrm{mg} \mathrm{g}^{-1}$. Model equations such as Langmuir and Freundlich isotherms were used to analyze the adsorption equilibrium data and the best fits to the experimental data were provided by the first isotherm model. Scanning electron microscopy and energy-dispersive X-ray (SEM-EDX), Brunauer-Emett-Teller (BET), Fourier transform infrared analyses (FTIR) and microbiological characterisation were also performed to characterize the biosorbent. To describe the adsorption mechanism, kinetic models such as pseudo-second-order and the intra particle diffusion were applied.
\end{abstract}

Keywords: Micropollution, Cationic Dyes, Biosorption, Dairy Sludge, Characterizations

\section{Introduction}

Colored industrial effluents are one of the most important issues of wastewater treatment, not only because of their high values of biochemistry oxygen demand (BOD), suspended solids and toxicity, but also the color that is considered the first visual contamination (Maurya et al. 2006; Otero et al. 2003). Dyes significantly affect photosynthetic activity in aquatic systems by reducing light penetration and can also be toxic because of the presence within their structure of aromatic compounds, metals, chlorides, etc.. (Gulnaz et al. 2004; Basibuyuk et al. 2003). Having a complex molecular structure and synthetic origin, making them biologically not degradable and resistant to environmental conditions, dyes are stable and difficult to treat (Yeddou 2006).

The use of adsorbents capable of trapping organic micropollutants is interesting in reducing the pollution level of contaminated water (Ho 2004). A number of studies have investigated the use of biosorbent (bacteria, algae and fungi), cheap and efficient, as an alternative or complement to existing techniques that are often expensive, inefficient and generates large amounts of sludge (Weng et al. 2006; Vasanth Kumar et al. 2005). Studies on the use of microorganisms, especially dead, for fixing dyes have been proved successful
(Mall et al. 2005). Living cells are susceptible to the toxic effect of organic matter and also require the input of nutrients (Deniz et al. 2010; Gupta et al. 2009). For these reasons, great interest is given to non-living biomaterials (Hameed 2008).

As a result, activated sludge from biological treatment plants is considered good biosorbents of dyes because of their richness in microorganisms (Aksu 2005). It is within this framework that we have studied the biosorption of an industrial dye (A-BG), in aqueous solution, by sludge from the treatment of wastewater of a dairy. The study focused on the influence of $\mathrm{pH}$ on biosorption, investigating biosorption's isotherms and kinetics at optimum $\mathrm{pH}$.

\section{Materials and Methods}

\subsection{Acquisition and Preparation of the Sludge and Dye Solutions}

The sludge was collected from drying beds (dairy complex Sidi-Khaled Tiaret), dried at $105^{\circ} \mathrm{C}$, crushed and sieved. The sample was kept in desiccators. The initial concentrations ranging from 5 to $100 \mathrm{mg} \mathrm{L}^{-1}$ were prepared from a stock solution of the industrial dye of $2 \mathrm{~g} \mathrm{~L}^{-1}$. 


\subsection{Characterization of Biosorbent}

The organic fraction was determined by sludge calcinations to constant weight. Microbiological characterization concerns the search for bacteria, fungi and algae. Scanning electronic microscopy (SEM) and X-ray spectrometry were used to characterize the biosorbent. Surface area is determined by the BET method.

\subsection{Experimental Protocol}

The study of biosorption is achieved by mixing a quantity of sludge $(10 \mathrm{mg})$ with $50 \mathrm{~mL}$ of dye solution. The whole is stirred for 2 hours at $120 \mathrm{rpm}$ at $20^{\circ} \mathrm{C}$ then centrifuged for $10 \mathrm{~min}$ at $4000 \mathrm{rpm}$. The unfixed dye in the supernatant was estimated by the spectrophotometric method at specific wavelength (Waranusantigula et al. 2003).

\subsubsection{Effect of $\mathrm{pH}$}

To determine the wavelength corresponding to maximum absorption of the dye we prepared a solution of $5 \mathrm{mg} \mathrm{L}-1$ and using the spectrophotometer, we measured the optical density by varying the wavelength from 500 to $700 \mathrm{~nm}$. To study the effect of $\mathrm{pH}$ on the absorption peak we performed the same way by varying each time the medium $\mathrm{pH}$ by adding a few drops of $\mathrm{NaOH}(1 \mathrm{~N})$ or $\mathrm{HCl}(1 \mathrm{~N})$ (Pala et al. 2002).

\subsubsection{Biosorption Isotherms}

This experiment is to evaluate the distribution of the solute (dye) at the adsorption equilibrium between the two phases present: (a) the liquid phase (dye in the solution with concentration, Ce) and the solid phase (dye adsorbed on the substrate, q). Evaluation of dye concentration on the support $\mathrm{q}(\mathrm{mg} \mathrm{g}-1)$ is carried by material balance:

$$
q=\frac{\mathrm{v}(\text { Co-Ce })}{\mathrm{m}} \text { (Demirbas et al. 2009) }
$$

Co is the initial dye concentration in the aqueous phase $\left(\mathrm{mg} \mathrm{L}^{-1}\right), \mathrm{V}$ the solution volume $(\mathrm{L})$ and $\mathrm{m}$ the mass of adsorbent used (g).

\subsubsection{Procedure}

A series of capped flasks containing $50 \mathrm{~mL}$ of dye solution of known concentrations, varying from 10 to $100 \mathrm{mg} / \mathrm{L}$ were prepared. Identical amounts $(10 \mathrm{mg})$ of sludge were added to the flasks and the resulting suspensions were agitated magnetically at $120 \mathrm{rpm}$ and $20{ }^{\circ} \mathrm{C}$ for $2 \mathrm{~h}$ at a constant $\mathrm{pH}$ of 5 and then centrifuged for $10 \mathrm{~min}$ at $4000 \mathrm{rpm}$. The unfixed dye in the supernatant was estimated by the spectrophotometric method at specific wavelength.

\subsubsection{Kinetic Studies}

In order to examine the adsorption controlling mechanism, kinetic models such as pseudo-second-order and the intra particle diffusion were applied to experimental data of the studied dye (Hameed et al. 2009). Kinetic experiments were conducted for different initial quantities $(10 \mathrm{mg}, 50 \mathrm{mg}, 100$ $\mathrm{mg} 150 \mathrm{mg}$ and $200 \mathrm{mg}$ ) of sludge to which identical volumes of dye solution $(50 \mathrm{mg} / \mathrm{L})$ were added in stirred flasks for $2 \mathrm{~h}$ at a speed of $200 \mathrm{rpm}$, a $\mathrm{pH}$ of 5 , and a temperature of $20{ }^{\circ} \mathrm{C}$. Solution samples were withdrawn at regular intervals, centrifuged and the dye concentration measured. Similar tests were performed by varying the initial concentration of dye $(50,100$ and $200 \mathrm{mg} / \mathrm{L})$ and the average particle diameter $(<80,125-250$ and $250-500 \mu \mathrm{m})$.

\section{Results and Discussion}

\subsection{Characterization of Biosorbent}

The analysis of the sludge gave a $65 \%$ of organic matter content and a presence of aerobic germs, total coliforms, staphylococcal, the streptococcus lactic ones, bacterial spores, yeasts and moulds, algae and protozoa.

Table 1. Chemical composition of the sludge, (SEM/DEX)

\begin{tabular}{lll}
\hline Element & \%Mass & \%Atomic \\
\hline $\mathrm{C}$ & 32.19 & 45.17 \\
$\mathrm{O}$ & 40.72 & 42.89 \\
$\mathrm{Mg}$ & 0.42 & 0.29 \\
$\mathrm{Al}$ & 0.64 & 0.40 \\
$\mathrm{Si}$ & 2.22 & 1.33 \\
$\mathrm{P}$ & 1.57 & 0.85 \\
$\mathrm{~S}$ & 0.45 & 0.24 \\
$\mathrm{~K}$ & 0.42 & 0.18 \\
$\mathrm{Ca}$ & 19.76 & 8.31 \\
$\mathrm{Fe}$ & 0.67 & 0.20 \\
$\mathrm{Sn}$ & 0.94 & 0.13 \\
$\mathrm{Total}$ & 100.00 & \\
\hline
\end{tabular}
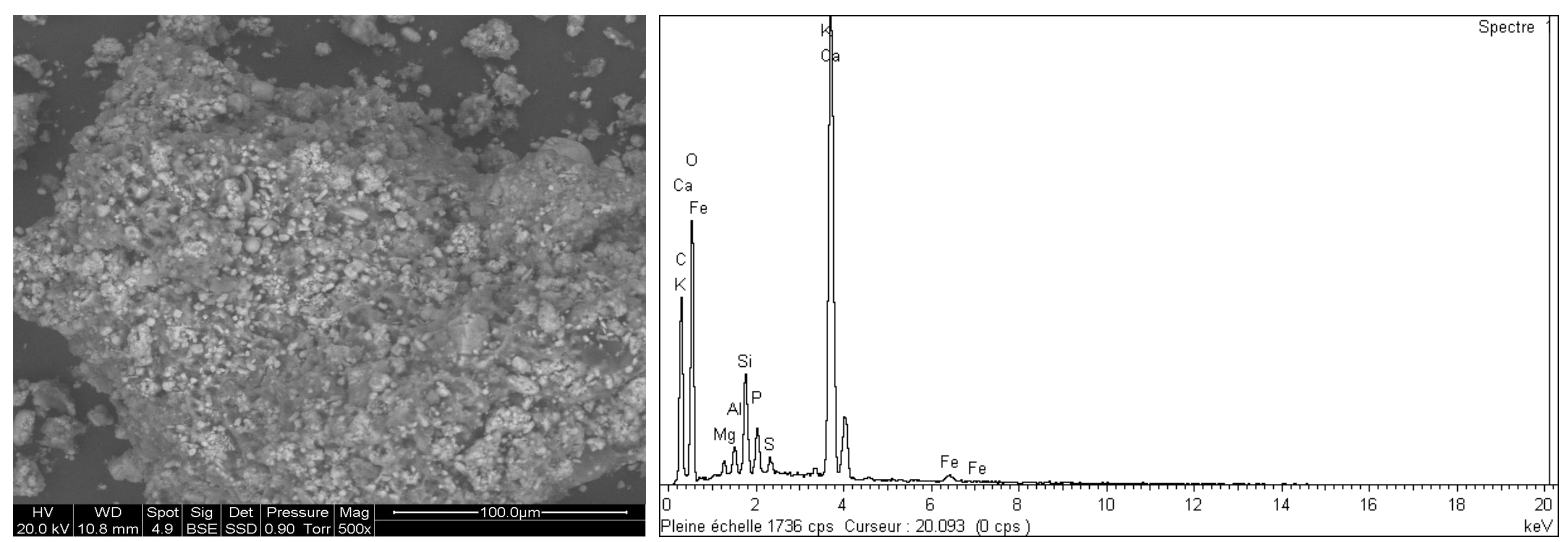

Fig. 1. Sludge's $S E M / E D X$ 
Table 1 summarizes the chemical composition of biosorbent used. Besides carbon and oxygen, high level of calcium was found in this sludge. The dairy wastewater is laden with lactoserum which is rich in calcium complexing proteins as in caseins, for instance. The sludge analysis by scanning electron microscopy coupled with energy dispersive $\mathrm{X}$-ray spectrometry (EDX) is shown in figure 1 . The specific surface area obtained by BET method is $1.22 \mathrm{~m}^{2} \mathrm{~g}^{-1}$.

\subsection{Dye's Structure}

The industrial dye AB-G or BB1 (called setoglaucine) is a cationic dye whose structure (triarylmethane class) is mentioned in figure 2 .

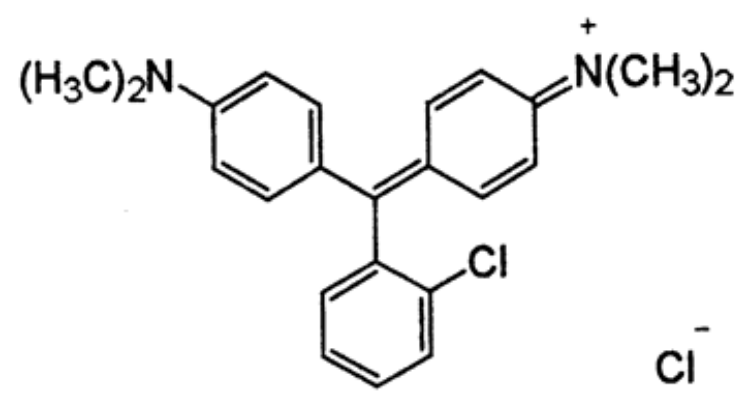

Fig. 2. A-BG structure, [Methanaminium, $N-[4-[(2-c h l o r o p h e n y l)[4-$ (dimethylamino)phenyl]methylene]-2,5-cyclohexadien-1-ylidene]-N-methyl,chloride (1:1)]

The dye presents the following characteristics:

Raw formula: $\mathrm{C}_{23} \mathrm{H}_{24} \mathrm{Cl}_{2} \mathrm{~N}_{2}$

Chemical Abstracts Service (CAS): $3521-6-\mathrm{O}$

Colour Index (CI) : 42025

\section{3. pH Effect}

The $\mathrm{pH}$ is a very important parameter that affects not only the ability of biosorption but also the color of the solution and the solubility of dye (Van der Zee 2002). Figure 3 shows the $\mathrm{pH}$ effect on the maximum absorption of dye. The maximum wavelength $\left(\lambda_{\max }\right)$ of dye is $650 \mathrm{~nm}$. We noticed that the peak absorption is not affected by the change in $\mathrm{pH}$.

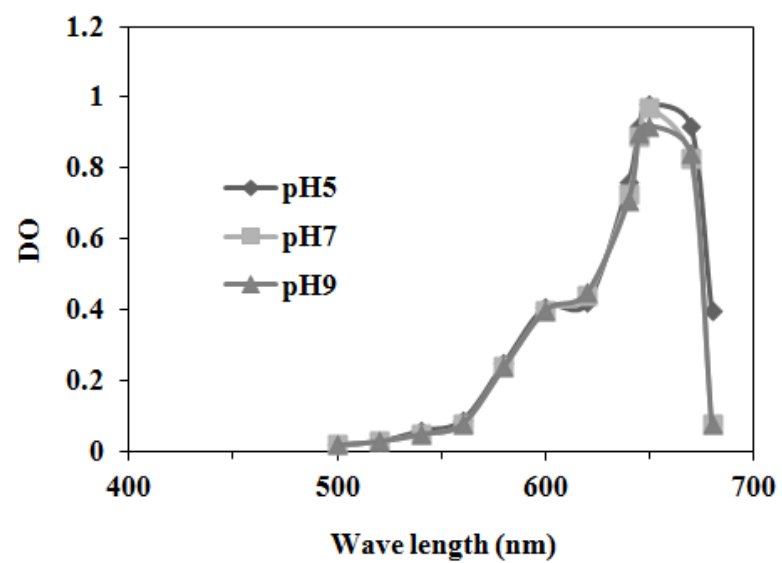

Fig. 3. Maximal optic density according to the $p H[A-B G]=5 \mathrm{mg} L^{-1}, T$ $\left(20^{\circ} \mathrm{C}\right), V=50 \mathrm{~mL}$

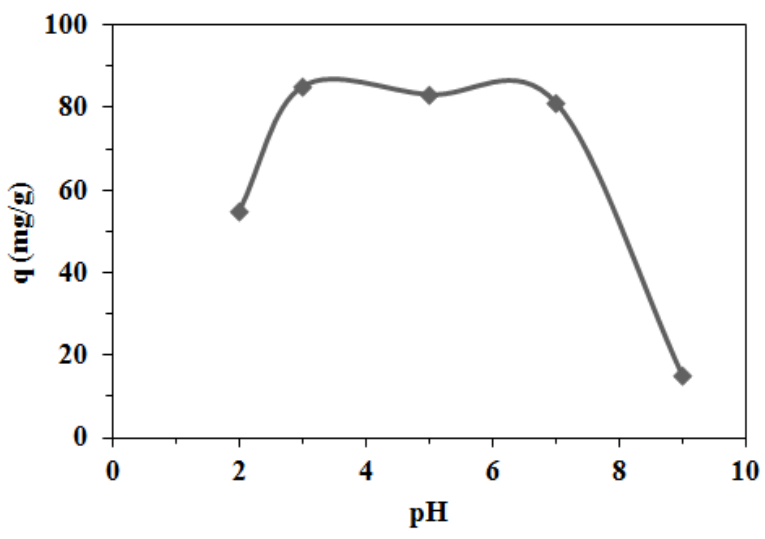

Fig. 4. Effect of $p H$ on $A-B G$ 's biosorption. Sludge $(10 \mathrm{mg})$; $[A-B G] 50 \mathrm{mg}$ $\mathrm{L}^{-1} ; \mathrm{T}\left(20^{\circ} \mathrm{C}\right)$; Stirring (120 rpm) ; Stirring time (2h)

According to Figure 4, dye fixation remains maximal ( $q=$ $80 \mathrm{mg} \mathrm{g}^{-1}$ ) from $\mathrm{pH} 3$ to $\mathrm{pH} 7$. We can say that the $\mathrm{pH}$ does not affect the biosorption of A-BG.

However we must consider the behavior of the dye and sludge at different $\mathrm{pH}$ values (Gibbs et al. 2003)[20]. Indeed, the Figure. 5 shows that the sludge tends to alkalize the medium for initial $\mathrm{pH}$ values between 5 and 8 . A similar case was found while fixing heavy metals $(\mathrm{Cr})$ by the sludge (Volesky 1995). According to Duangrat et al. (2004), the pH values between 3 and 7 has no significant effect on the binding of Astrazon (6B), which is explained by the fact that at this $\mathrm{pH}$ interval the cationic dye is always positively charged. The increase in dye uptake at low $\mathrm{pH} 2$ may be due to the high concentration of $\mathrm{H}+$ ions in the aqueous solution competing with the dye molecules for the available sites on the adsorbent surface (Nemchi et al. 2012). Beyond pH 7, the binding decreases significantly which could be explained by the discoloration of the dye.

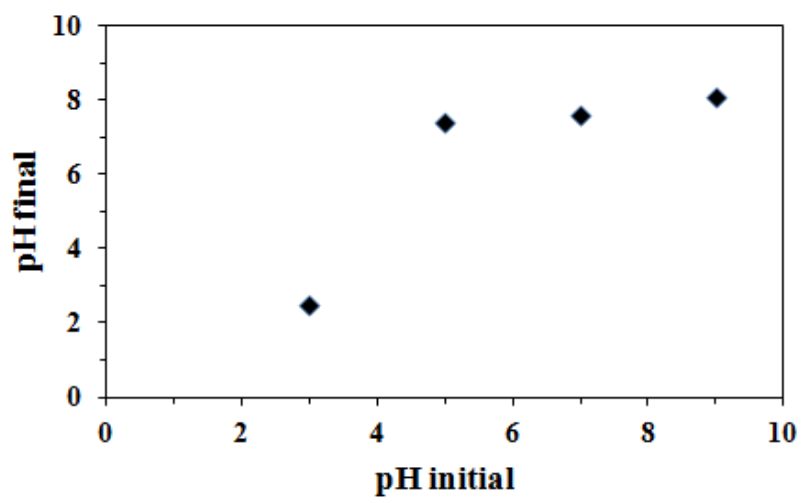

Fig. 5. Final $p H$ variation according to initial $p H$. Sludge (10 $\mathrm{mg}) ;[A-B G]$ $50 \mathrm{mg} \mathrm{L}^{-1}$; $\mathrm{T}\left(20^{\circ} \mathrm{C}\right)$; Stirring (120 rpm) ; Stirring time (2h)

\subsection{Biosorption Isotherm}

In order to evaluate the applicability of biosorption as a means of removing A-BG dye from aqueous solutions, two frequently used single-component adsorption isotherm models were considered in this study to describe the interaction between the adsorbate and the biosorbent, viz. the Langmuir and Freundlich isotherms. Both models represent 
the affinity of the adsorbate for the biosorption sites on the biosorbent surface. These isotherms (Sassi et al.2010) are represented by the following linearized equations:

Langmuir equation:

$$
\frac{\mathrm{C}_{\mathrm{e}}}{\mathrm{q}}=\frac{1}{\mathrm{q}_{\mathrm{m}}} \times \mathrm{C}_{\mathrm{e}}+\frac{1}{\mathrm{bq}_{\mathrm{m}}}
$$

where $\mathrm{q}$ is amount of solute biosorbed per unit weight of biosorbent $(\mathrm{mg} / \mathrm{g})$. Ce is the concentration of solute remaining in solution at equilibrium $(\mathrm{mg} / \mathrm{L}) . \mathrm{q}_{\mathrm{m}}(\mathrm{mg} / \mathrm{g})$ is the maximum biosorption capacity corresponding to complete monolayer coverage and $\mathrm{b}$ is a constant related to the energy or net enthalpy.

Freundlich equation:

$$
\log q=\log k+\frac{1}{n} \log C_{e}
$$

where $\mathrm{k}$ and $\mathrm{n}$ are the Freundlich constants related to biosorption capacity and biosorption intensity that can be obtained from the intercept and slope of log q vs. $\log$ Ce plot

Figure 6, representing the amount of fixed dye depending on its concentration at equilibrium, shows an increase in the discoloration reached a limit value $\left(120 \mathrm{mg} \mathrm{g}^{-1}\right)$ obtained for an equilibrium concentration of $20 \mathrm{mg} \mathrm{L}^{-1}$.

Table 2 allows us to determine the parameters for the two models. These data were well fitted by Langmuir isotherm model with $\mathrm{R}^{2}=0.91$.

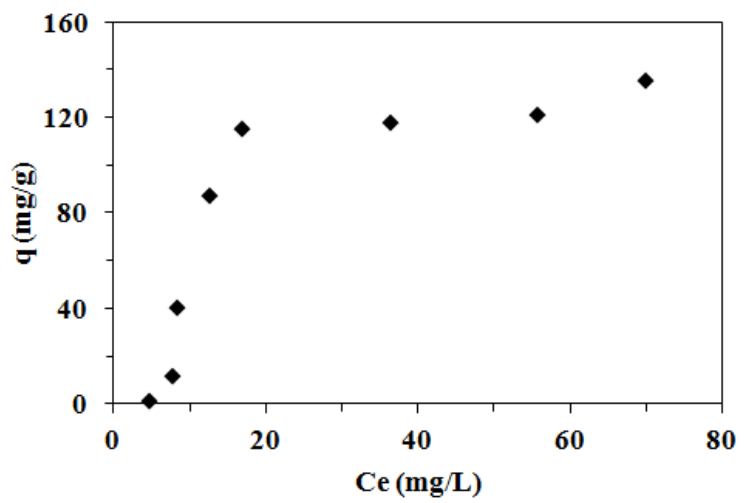

Fig. 6. $A-B G$ 's isotherm of fixation Sludge $(10 \mathrm{mg}) ; \mathrm{T}\left(20^{\circ} \mathrm{C}\right)$; Stirring $(120$ rpm); Stirring time (2h)

Table. 2. Langmuir and Freundlich isotherm parametersfor $A-B G$ 's biosorption by the sludge at $\mathrm{pH} 5$ and $20^{\circ} \mathrm{C}$.

\begin{tabular}{llllll}
\hline & Langmuir & \multicolumn{3}{c}{ Freundlich } \\
\hline $\mathrm{q}_{\max }\left(\mathrm{mg} \mathrm{g}^{-1}\right)$ & $\mathrm{b}$ & $\mathrm{R}^{2}$ & $\mathrm{k}$ & $\mathrm{n}$ & $\mathrm{R}^{2}$ \\
178.6 & 0.06 & 0.91 & 17.75 & 1.94 & 0.64 \\
\hline
\end{tabular}

\subsection{Kinetic Studies}

The biosorption of a dye in the liquid phase is controlled by various steps including diffusion processes and phases of fixing itself. If we exclude the movement of solute from the solution to the boundary layer surrounding the adsorbent particle, the process of adsorption in porous solids can be divided into three parts: a) Transfer of solute from film to the external adsorbent surface. It's the external diffusion.

b) Distribution of solute from the surface to internal sites. It's the intraparticle diffusion.

c) Fixing the solute on the adsorbent sites. This step is the adsorption (Ho et al. 2000).

When more than one step are present, intraparticle diffusion is not the sole limiting step. Sorption itself can be accounted for by several interactions between the metal ions and the sorbent due to the numerous and complex surface functional groups present on the sludge. The kinetics of biosorption, representing the rate of biosorption of the biosorbate controlled by the residence time in the solidliquid interface is the principal characteristic defining the biosorption efficiency (Crini et al. 2008).

\subsubsection{Effect of Sludge Amount}

In Figure 7 we noted that the quantity not fixed relative to the initial amount $(\mathrm{Ce} / \mathrm{Ci})$ is about 0.5 for quantities of sludge of 10,50 and $100 \mathrm{mg}$. It falls below 0.4 for $150 \mathrm{mg}$ of sludge and almost vanishes for the amount of biosorbent 200 mg. In fact, according to Birol (2011), increasing the amount of biosorbent enables high availability of binding sites which results in a rapid decrease in dye concentration in the solution. For different concentrations of sludge maximum dye is removed during the first 20 minutes.

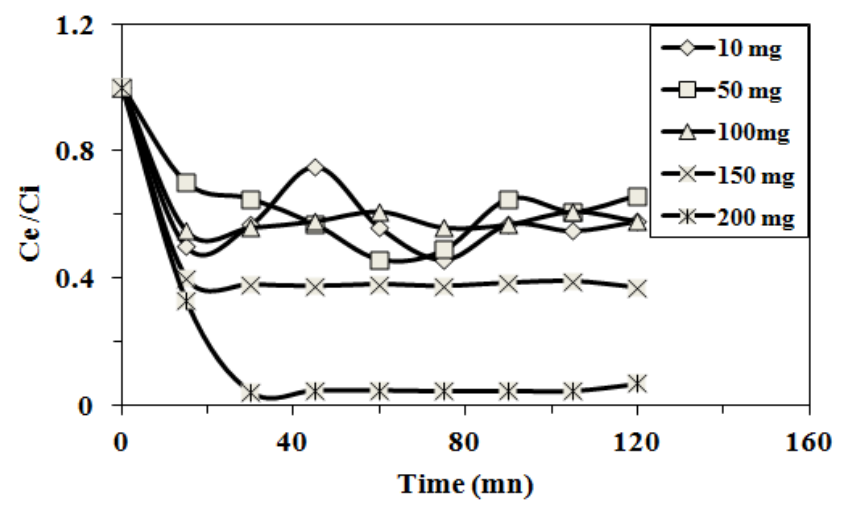

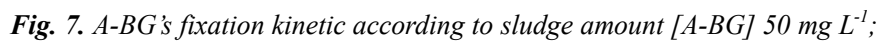
$T\left(20^{\circ} \mathrm{C}\right)$; Stirring $(120 \mathrm{rpm})$

\subsubsection{Effect of Particles Size}

The kinetics of attachment allow the access to speeds of fixation.These kinetics can be controlled by diffusion mechanisms (external, intra-particle). The intra particle diffusion is often the limiting step of the kinetic process, for this reason, experiments will be done based on the particle size.

Figure 8 shows that the maximum discolorization $(\mathrm{Ce} / \mathrm{Ci}$ $=0.5$ ) is obtained again after the first 20 minutes with a slight performance for diameter of 125 microns. Indeed, the low porosity can develop a large area and therefore a better dye binding (Hameeda et al. 2008). However, in order to minimize losses of biosorbent, the diameter of 500 microns is chosen for different experiments. 


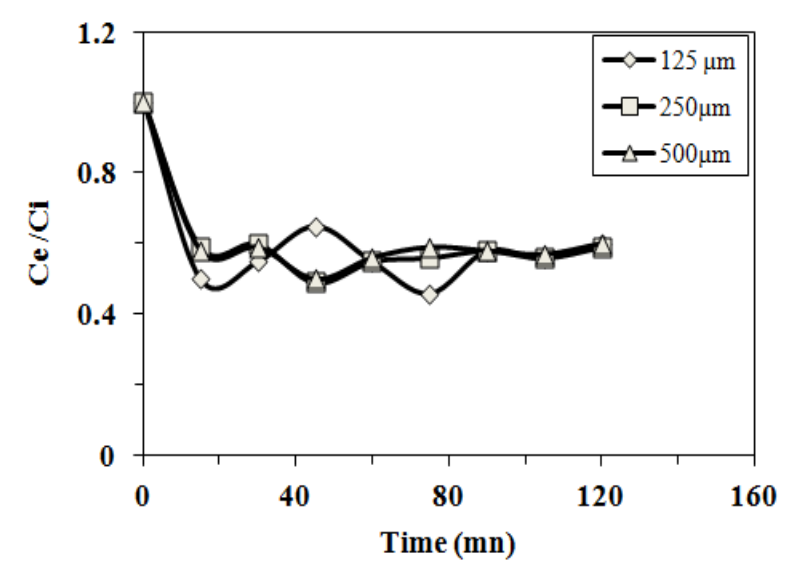

Fig. 8. A-BG's fixation kinetic according to particle diameter [A-BG] $50 \mathrm{mg}$ $L^{-1} ; T\left(20^{\circ} \mathrm{C}\right)$; Stirring (120 rpm)

\subsubsection{Effect of Initial Concentration of Dye}

From Figure 9, the kinetic of discoloration is highest during the first 20 minutes and stabilizes beyond and for the initial concentration of $50 \mathrm{mg} \mathrm{L}^{-1}$. For other concentrations the time required to reach equilibrium is slightly elongated (30 to 40 minutes).

The data from kinetic study were analyzed using the second order model described by the following equation:

$$
\frac{d q_{t}}{d t}=k\left(q_{e}-q_{t}\right)^{2}
$$

whose integration gives the linear form:

$$
\mathrm{tq}=\frac{1}{\mathrm{k}_{2} \mathrm{q}_{\mathrm{e}}^{2}}+\frac{\mathrm{t}}{\mathrm{q}_{\mathrm{e}}}
$$

where $\mathrm{k}_{2}$ is the constant rate of biosorption, $\mathrm{q}_{\mathrm{e}}$ the amount of dye attached at equilibrium and $q_{t}$ the quantity fixed at time.

The kinetic parameters are confined in Table 3 . For the concentration parameter, it should be noted that the second order model can be applied especially well for the first two concentrations (50 and $100 \mathrm{mg} \mathrm{L}^{-1}$ ) with a correlation coefficient exceeding $96 \%$. However, it should be noted the difference between the value of calculated and experimental $\mathrm{q}_{\mathrm{e}}\left(120 \mathrm{mg} \mathrm{L}^{-1}\right)$. For the constant $\mathrm{k}_{2}$, its value decreases with increasing initial concentration (Basibuyuk et al. 2003). The kinetic study of biosorption according to the particle diameter parameter follows well the second order model. This is confirmed by the value of $\mathrm{R}^{2}$ and that of $\mathrm{q}_{\mathrm{e}}$ calculated. In the case of the third parameter, despite a correlation coefficient that reached $99 \%$, the calculated value of $\mathrm{q}_{\mathrm{e}}$ is much away of the experimental value.

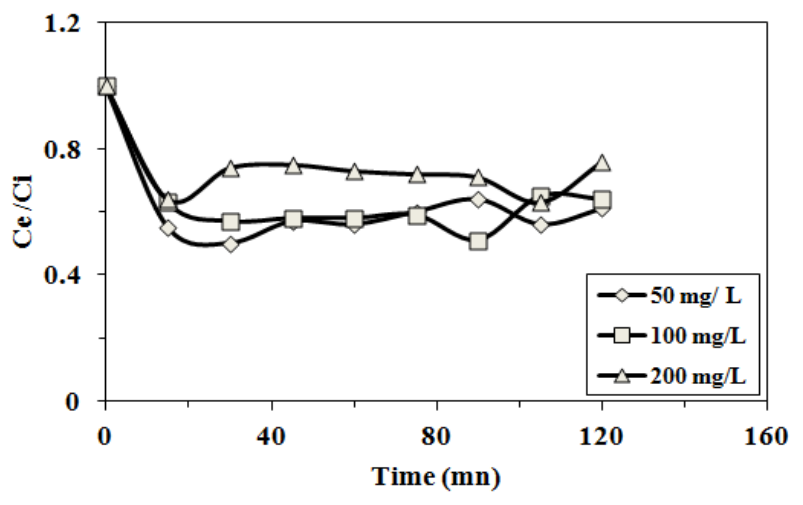

Fig. 9. A-BG's fixation kinetic according to its initial concentration

Table. 3. $A-B G$ 's second order kinetic parameters

\begin{tabular}{lccc}
\hline & $\mathbf{q}_{\mathbf{e}}\left(\mathbf{m g ~ g}^{-\mathbf{1}}\right)$ & $\mathbf{k}_{\mathbf{2}}\left(\mathbf{m g ~ g}^{-1} \mathbf{m n}^{-\mathbf{1}}\right) \mathbf{1 0} \mathbf{0}^{-\mathbf{3}}$ & $\mathbf{R}^{\mathbf{2}}$ \\
\hline Init. conc. $\left(\mathrm{mg} \mathrm{L}^{-1}\right)$ & & & \\
50 & 92.59 & 3.67 & 0.97 \\
100 & 166.67 & 0.96 & 0.96 \\
200 & 256.41 & 0.71 & 0.85 \\
Ø particles $(\mu \mathrm{m})$ & & & \\
125 & 102.04 & 4.70 & 0.93 \\
$125-250$ & 103.09 & 1.99 & 0.96 \\
$250-500$ & 98.04 & 4.86 & 0.97 \\
Sludge amount(mg) & & & \\
50 & 38.17 & 6.65 & 0.99 \\
100 & 7.24 & 10.34 & 0.90 \\
200 & 12.24 & 36.57 & 0.99 \\
\hline
\end{tabular}

\subsection{Study of Intra-Particle Diffusion}

The possibility of intra-particle diffusion is exploited using the model of Morris and Weber:

$\mathrm{q}_{\mathrm{t}}=\mathrm{k}_{\mathrm{id}} \mathrm{t}^{1 / 2}$ where $\mathrm{k}_{\mathrm{id}}$ is a rate constant of intra-particle diffusion $\left(\mathrm{mg} \cdot \mathrm{g}^{-1} \cdot \mathrm{min}^{-1 / 2}\right)$. According to this equation the representation $q_{t}$ according to $t^{1 / 2}$ (Figures 10, 11 and 12) could be linear if the diffusion is involved and if these lines pass through the origin then the movement of the adsorbate is controlled by intra-particle diffusion. Otherwise other kinetic models may be factors limiting the rate of biosorption (Attouti et al. 2013).

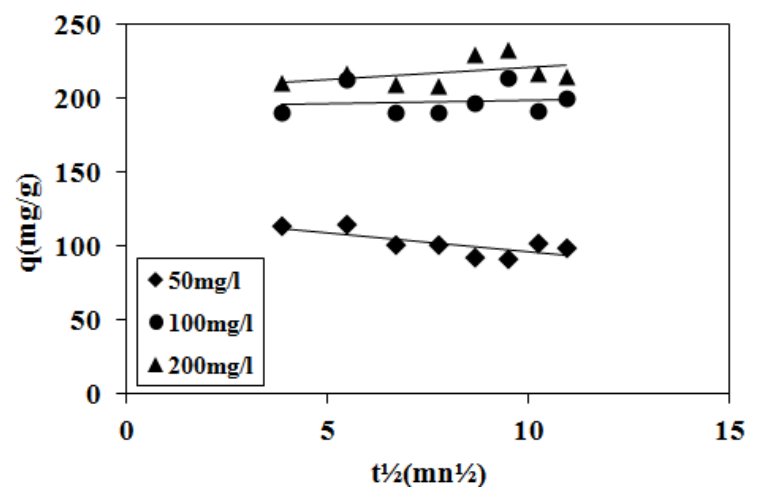

Fig. 10. Effect of dye concentration on its intraparticle diffusion 


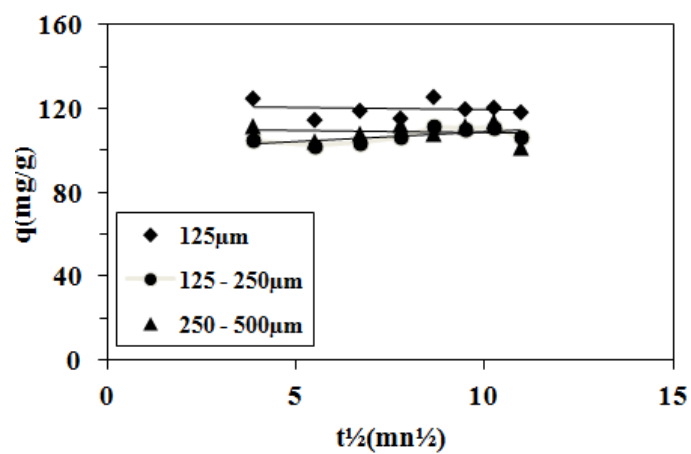

Fig. 11. Effect of particles diameter on the intraprticle diffusion of the dye



Fig. 12. Effect of sludge amount on dye's intraparticle diffusion

\section{Conclusion}

With the unlimited release of wastewater carrying out pollutants, the treatment has become a priority. Biosorption constitutes a new efficient and inexpensive biological treatment process. This study has shown that dairy sludge is effective biosorbent for the removal of dye used in textile industry due to its richness in microorganisms. Indeed the maximum discoloration is achieved using $10 \mathrm{mg}$ of sludge and during the first 20 minutes. This setting does not seem to be affected by particles diameter and the $\mathrm{pH}$ between 3 and 7 did not affect dye biosorption. The initial concentration has little effect on the equilibrium time. Biosorption of this dye follows especially the Langmuir model $(\mathrm{R} 2=0.91)$ which allowed us to determine the maximum dye fixation that is $178.6 \mathrm{mg} \mathrm{g}^{-1}$. Kinetics studies showed that biosorption process obeyed the pseudo-second- order rate model. The mechanism of dye's biosorption is partly explained by the model of intra-particle diffusion which does not seem to be the only part controlling that process. This study showed that dairy sludge can be an alternative to the commercially available adsorbents for dyes removal from liquid effluents.

\section{References}

[1] Aksu Z., (2005). Application of biosorption for the removal of organic pollutants: a review. Process Biochemistry (40), 9971026.

[2] Attouti S., Bestani B., Benderdouche N., and Duclaux L., (2013). Application of Ulva lactuca and Systoceira stricta algae-based activated carbons to hazardous cationic dyes removal from industrial effluents, water research (47), 33753388.

[3] Basibuyuk M. Forster C.F., (2003). An examination of the adsorption characteristics of a basic dye (Maxilon Red BL-N) on to live activated sludge system. Process Biochemistry (38), $1311 / 1316$.

[4] Birol K., (2011). Adsorption of textile dyes onto iron based waterworks sludge from aqueous solution; isotherm, kinetic and thermodynamic study. Chemical Engineering Journal (173), 782- 791 .

[5] Crini G., Badot P. M., (2008). Application of chitosan, a natural aminopolysaccharide, for dye removal from aqueous solutions by adsorption processes using batch studies: A review of recent literature. Prog. Polym. Sci. (33), 399-447.

[6] Demirbas E., Nas M.Z., (2009). Batch kinetic and equilibrium studies of adsorption of Reactive Blue 21 by fly ash and sepiolite. Desalination (243), 8-21.

[7] Deniz F., Saygideger S.D, (2010). Equilibrium, kinetic and thermodynamic studies of Acid Orange 52 dye biosorption by Paulownia tomentosa Steud. Leaf powder as a low-cost natural biosorbent. Bioresour. Technol. (101), Issue 14, 5137 5143.

[8] Duangrat I., Siritham S., (2004). Decolorization of basic,direct and reactive dyes by pre-treated narrow-leaved cattail (Typha angustifolia Linn.). Bioresource Technology (94), 299 -306.

[9] Gibbs G., Tobin J. M., Guibal E., (2003). Sorption of Acid Green 25 on Chitosan:Infuence of Experimental Parameters on Uptake Kinetics and Sorption Isotherms. Journal of Applied Polymer Science, (90), $1073-1080$.

[10] Gulnaz O., Kaya A., Matyar F., Arikan B., (2004). Sorption of basic dyes from aqueous solution by activated sludge. Journal of Hazardous Materials B (108), 183-188.

[11] Gupta V.K., Suhas, (2009). Application of low-cost adsorbents for dye removal - A review. Journal of Environmental Management (90), 2313-2342.

[12] Hameeda B.H., El-Khaiaryb M.I., (2008). Malachite green adsorption by rattan sawdust: Isotherm, kinetic and mechanism modeling. Journal of Hazardous Materials (159), 574-579.

[13] Hameed B.H., (2008). Equilibrium and kinetic studies of methyl violet sorption by agricultural waste. Journal of Hazardous Materials, (154), 204-212.

[14] Hameed B.H., Ahmad A.A., Aziz N., (2009). Adsorption of reactive dye on palm-oil industry waste: Equilibrium, kinetic and thermodynamic studies, Desalination (247) 551-560.

[15] Ho, Y.S., McKay, G., (2000). The kinetics of sorption of divalent metal ions onto sphagnum moss peat. Water Research, (34) $735-742$

[16] Ho Y.-S., (2004). Comment on "Sorption of basic dyes from aqueous solution by activated sludge". Journal of Hazardous Materials B (114), 241-245.

[17] Mall I. D., Srivastava V. C., Agarwal N. K., Mishra I. M., (2005). Adsorptive removal of malachite green dye from aqueous solution by bagasse fly ash and activated carbonkinetic study and equilibrium isotherm analyses. Colloids and Surfaces A: Physicochem. Eng. Aspects (264), 17-28. 
[18] Maurya N. S., Mittal A. K. and Cornel P., (2006). Bio sorption of dyes using dead macro fungi. Bioresource Technology (97), $512-521$.

[19] Nemchi F., Bestani B., Benderdouch N., Belhakem M. and Charles de Minorval L., (2012). Adsorption of Supranol Yellow 4GL from Aqueous Solution onto Activated Carbons Prepared from Seawater Algae. Adsorption Science \& Technology (30) 1, 81-95.

[20] Otero M., Rozada F., Calvo L.F., Garc'ýa A.I., Morán A., (2003). Kinetic and equilibrium modelling of the methylene blue removal from solution by adsorbent materials produced from sewage sludges. Biochemical Engineering Journal (15), $59-68$.

[21] Pala A., Tokat E., (2002). Color removal from cotton textile industry wastewater in an activated sludge system with various additives. Technical note, Water Research (36), 2920 2925.

[22] Sassi, M., Bestani, B., Hadj Said, A., Benderdouche, N., Guibal, E., (2010). Removal of heavy metal ions from aqueous solutions by a local dairy sludge as a biosorbent. Desalination 262 (1-3), 243-250.

[23] Vasanth Kumar K., Sivanesan S., Ramamurthi V., (2005). Adsorption of malachite green onto Pithophora sp., a fresh water algae: Equilibrium and kinetic modeling. Process Biochemistry (40), 2865-2872.

[24] Van der Zee F.P., (2002). Anaerobic azo dye reduction. Doctoral Thesis, Wageningen University, Wageningen, The Netherlands, 142 pages.

[25] Vasanth Kumar K., Ramamurthi Sivanesan V., S., (2006). Biosorption of malachite green, a cationic dye onto Pithophora sp., a fresh water algae. Dyes and Pigments (69), 102-107.

[26] Volesky B., (1995). Bio sorption of heavy metals. Biotech. Prog (11), 235-250. agricultural waste. Journal of Hazardous Materials (154) 204-212.

[27] Waranusantigula P., Pokethitiyooka P., Kruatrachuea M., Upatham E.S., (2003). Kinetics of basic dye (methylene blue) biosorption by giant duckweed (Spirodela polyrrhiza). Environmental Pollution (125), 385-392.

[28] Weng C. H. and Pan Y. F., (2006). Adsorption characteristics of methylene blue from aqueous solution by sludge ash. Colloids and Surfaces A: Physicochem. Eng. Aspects (274), 154-162.

[29] Yeddou N. et Bensmaili A., (2006). Equilibrium and kinetic modelling of methylen blue biosorption by pretreated dead fugi. Chemical Engineering Journal (119), 119-125. 